*Doutor em Direito pela Universidade Federal de Santa Catarina. Doutor em Ciência Política pela Universidade Federal Fluminense. Doutor em Ciências Jurídico-Sociais pela Universidad del Museo Social Argentino. Mestre em Direito pela Universidade Federal de Santa Catarina. Especialista em Direito Tributário. Bacharel em Direito pela Universidade Estadual Vale do Acaraú. Email: diegosaboiaesilva@gmail.com

\footnotetext{
**Doutorado em andamento pela Universidade Federal de Santa Catarina. Mestre em Direito pela Universidade Federal de Santa Catarina. Especialista em Direito e Processo Constitucional pela Universidade Estadual Vale do Acaraú. Bacharel em Direito pela Universidade Estadual do Vale do Acaraú. Email: davidgpontes@, yahoo.com.br
}

\section{A Doutrina Do Tribunal Multiportas E A Sua Aplicabilidade Nos Juizados Especiais Cíveis Do BRASIL}

\author{
The Multi-Door Court And Its Applicability In The \\ Small Claims Courts Of Brazil
}

\section{Diego Sabóia e Silva* David Gomes Pontes**}

Como citar: SILVA, Diego Sabóia e; PONTES, David Gomes. A doutrina do tribunal multiportas e sua aplicabilidade nos juizados especiais cíveis do Brasil. Scientia Iuris, Londrina, v. 24, n. 1, p. 39-54, mar. 2020. DOI 10.5433/21788189.2020v24n1pX. ISSN 2178-8189.

Resumo: O presente artigo possui por objetivo geral verificar em que consiste a doutrina do Tribunal Multiportas, assim como sua incidência no âmbito dos Juizados Especiais Cíveis - JEC's no Brasil. Como propósitos específicos, intenta-se inicialmente explicar a origem de referida teoria, a partir da perspectiva atribuída por Frank Sander, na Universidade de Harvard, nos Estados Unidos; após, discute-se sua recepção em terras brasileiras, adotando-se como base sua aplicabilidade nos JEC's à luz da evolução legislativa e possíveis situações que inviabilizam a efetivação de seu propósito, a saber, a pacificação social alcançada pelo meio mais adequado de prevenção ou reparação de conflitos de interesses disponíveis; e, por fim, analisa-se o novel perfil exigido dos profissionais da advocacia nessa conjuntura de desestímulo à judicialização. Por fim, à guisa de verificação da aderência da proposta à realidade circundante, faz-se análise de caso concreto hipotético que envolve o direito de vizinhança e mecanismos de defesa possessórios.

Palavras-chave: Tribunal multiportas. Aplicabilidade. Juizados especiais cíveis. Brasil.

Abstract: This paper's objective is to verify the use of the Multidoor Court, as well as its possible adoption in Brazilian Small Claims Courts - JECs. Firstly, this study explores this important institution's origins, from the perspective of Frank Sander, a Harvard University professor. Secondly, this paper discusses its possible use in Brazil's JECs. Unfortunately, some court practices impair its purpose. Finally, this study investigates how legal professionals handle situations that do not need to immediately 
involve the judicial process. Finally, in order to verify the acceptance of the proposal in its surrounding reality, this paper examines a specific case that involved the right of neighborliness and the defense of possessions.

Keywords: Multidoors Court. Applicability. Small Claims Court. Brazil. 


\section{INTRODUÇÃO}

A temática em escopo consistirá em analisar a função dos Juizados Especiais Cíveis JEC's - brasileiros como Tribunal Multiportas, no sentido de direcionar os processos que a estes se apresentam aos mais adequados métodos de resolução de conflitos (à guisa exemplificativa: mediação, conciliação, arbitragem, rent a judge, ombudsman), privilegiando-se a celeridade e a economia tanto para o Poder Judiciário quanto para as partes envolvidas e, por consectário lógico, a eficiência e a adequação processuais.

Para tanto, são objetivos centrais deste artigo apresentar o contexto onde se originou e se desenvolveu a doutrina do Tribunal Multiportas, a saber, nos Estados Unidos da América, em espaço cuja tradição jurídica é anglo-saxônica, ou de Common Law, não sendo este fator impeditivo para a aplicação em país de cultura romano-germânica, ou de Civil Law, como o Brasil. Ademais, analisar-se-á como se deu a assimilação dessa teoria em âmbito brasileiro, com ênfase transcurso legal experimentado pelos JEC's, assim como quais fatores se afiguram como obstáculos à sua implementação e possíveis medidas a serem adotadas para superação da "cultura da sentença" em terrae brasilis.

Imperioso advertir que é da própria natureza do Tribunal Multiportas o "socorro" ao Poder Judiciário em âmbito contencioso apenas quando as formas de resolução de conflitos adequadas (ou alternativas) sugeridas não conseguirem dar vazão satisfatória ao litígio. Dessa forma, não há, como regra, prejuízo da via jurisdicional, mas apenas estímulo à adoção de outros meios que, ao menos inicialmente, são reputados como mais idôneos do ponto de vista da verdadeira pacificação social.

Tal sistemática, à luz da experiência brasileira, visa conferir efetividade aos cânones estabelecidos na lei no 9.099/1995, observados, por óbvio, os assuntos de competência dos JEC's. Em assim sendo, a pergunta que servirá de móbil para a pesquisa adiante assume a seguinte forma: quais são os possíveis óbices para a plena aplicabilidade dos preceitos estabelecidos pela lei dos JEC's, em especial os da celeridade processual e da efetiva resolução dos conflitos, pacificando o social?

Como hipótese, ponderar-se-á que há a necessidade de se compreender que a própria tradição jurídica brasileira de judicialização - a "cultura da sentença”" (FERREIRA; GUANABARA; JORGE, 2011, p. 26) - por vezes inviabiliza a efetivação da doutrina em escopo, pois, por mais que perante a sociedade em geral e a classe advocatícia possa haver descrédito do Poder Judiciário com a morosidade processual, ainda assim os mecanismos alternativos de resolução de conflitos de interesses disponíveis não raro são preteridos.

Como se não bastasse isso, há ainda o sério risco que as decisões judiciais, para além de morosas e não resolutivas de conflitos, ainda não tragam consigo qualquer paralelo com os limites estabelecidos pelo ordenamento jurídico, dado o recrudescimento do cognominado realismo jurídico. Consoante Ferreira, Guanabara e Jorge (2011, p. 85-86): 
Tal como a jurisprudência sociológica, o realismo é fundamentalmente antiformalista. Os adeptos desse movimento tinham por principal objetivo desmistificar o processo de aplicação do direito positivo pelos juízes, tentando pensar "realisticamente" os problemas legais. Por "realisticamente" deve-se entender uma preocupação em pôr à prova os dogmas legais que "camuflavam" uma defasagem entre as formas prescritas de atuação, as justificativas declaradas, e os comportamentos que eram de fato adotados pelos juízes. Rejeitavam, por isso, qualquer especulação filosófica sobre o significado do direito, o que redundaria, segundo eles, em definições excessivamente metafisicas. $\mathrm{O}$ atributo "realista" significava, ainda, uma refutação da teoria oficial do common law, no que diz respeito, principalmente, ao dogma de não construção do direito pelo juiz. Este deveria, segundo entendimento doutrinário predominante, limitar-se a aplicar as regras preexistentes (os precedentes e os estatutos). Os realistas fazem naufragar essa doutrina, demonstrando que ela é impossível na prática, sendo necessário, portanto, abandonar as ficções doutrinais e reconhecer abertamente o papel decisivo do juiz no funcionamento do sistema jurídico.

Nesse contexto ressai como vital a adoção de postura proativa e negociadora dos profissionais da advocacia, preferindo a consensualidade à contenciosidade. Metodologicamente, utilizar-se-á o método de abordagem dedutivo; como método de procedimento, o monográfico; e como técnica de pesquisa, a bibliográfica. Em síntese, esse o panorama do estudo que ora se passa a descortinar.

\section{DAS MÚltiplas FORMAS DE SOLUÇÃO DE CONFLITOS: A DOUTRINA DO TRIBUNAL MULTIPORTAS}

Em estudos históricos acerca da origem da sociedade civil e do Estado, em especial aqueles conduzidos por Locke, um dos autores conhecidos como "contratualistas", demonstrase que a ocorrência de conflitos sempre foi algo ínsito à convivência humana, sendo a força, na maioria das vezes, o meio empregado para solucioná-los.

Essa consciência da conflituosidade como algo ínsito à natureza humana conduziu a questionamentos acerca do modo como a sociedade tratou, ao longo do tempo, as formas de solução de tais conflitos. Locke (2019, p. 389) já registrava que, antes da existência do Estado, diante da ausência de uma autoridade constituída, tinha o homem o direito de punir o agressor de sua família ou de seus bens.

Todavia, ainda segundo Locke (2019, p. 496-499), essa mesma liberdade de repelir violentamente as agressões expunha o homem a atos de violência e violação por parte dos outros homens, que muitas vezes não observavam a justiça e a equidade na prática da autotutela. Essa realidade levou os homens a unirem-se em sociedade política, adotando normas que regulavam previamente as condutas e estabeleciam autoridades competentes dotadas de poder para aplicá-las, com vistas a tutelar a propriedade.

O ambiente no estado de natureza já era, obviamente, regulado por normas sociais, tanto que Locke (2019, p. 435) registra, por exemplo, a existência de autoridade dos pais sobre os filhos ou, até mesmo, a indisponibilidade do direito à vida (2019, p. 407). Estribando-se em Holmes 
e Sunstein (2019, p. 194), tem-se que as normas sociais e as normas legais resolvem problemas similares por meios diferentes.

Quando aquelas funcionam bem, estas se fazem desnecessárias. Todavia, quando falham, é provável que a sociedade passe a reclamar por direitos, sendo esta a provável razão de haverse migrado de um estado de natureza para um estado de direito, como, por exemplo, o direito de propriedade, alvo de ataques. A semelhante conclusão chega Vattel (2016, p. 30-32), ao afirmar que "a lei natural no estado de natureza não é ausente, mas também não é eficaz". Assim, o dever ser da obrigação natural não pode ser efetivo se não se transformar no dever ser da obrigação civil.

Com a instituição do Estado, conferiu-se tal poder de ditar o direito, com o reforço do emprego da coercibilidade, ao Poder Judiciário. Mendes (2008, p. 100-101), em capítulo de sua obra que dedica à análise do pensamento de Jeremy Waldron acerca da legitimidade do legislador frente aos desacordos morais, registra que, na atuação do Poder Judiciário, o que interessa é quem decide (visão procedimental), e não o que decide (visão substancial), posto que os desacordos morais dos homens sempre existirão, ou seja, eles sempre divergirão acerca do bem e do mal.

As decisões judiciais são obrigatórias em razão de seu procedimento, e não de sua substância. Se assim não o fosse, haveria a possibilidade de se discordar do que fora decidido e descumprir a decisão, voltando-se ao estado de natureza. Tal pensamento funda-se em Hobbes (2018, p. 23), para quem o que interessava era defender a autoridade do poder soberano.

O Poder Judiciário, durante muito tempo, apresentou-se como única alternativa à solução de conflitos. Fato é, porém, que, no caso brasileiro, vive-se uma realidade em que o Poder Judiciário apresenta custos elevadíssimos e não tem se mostrado capaz de eficientemente fazer frente ao grande número de processos novos que, anualmente, aportam ao sistema de justiça e se somam aos que lá já se acumulam.

Segundo o Conselho Nacional de Justiça (CNJ, 2018), somente no ano de 2017 foram ajuizados 29,1 milhões de processos, sendo óbvio que tal quantitativo não corresponde ao número de relações conflituosas vivenciadas no país, haja vista que muitas delas não chegam a ser judicializadas. Watanabe (2018, p. 91) registra textualmente o fato de o Poder Judiciário brasileiro viver uma crise em termos de "morosidade, efetividade e adequação de suas soluções".

Além de não dar conta de atender à demanda, não se pode fechar os olhos para o fato segundo o qual o método judicial de resolução de conflitos, segundo Entelman (2009, p. 26), “é uma técnica de prevenção e resolução de conflitos que recorre à violência”. Portanto, dadas as limitações estruturais e de tempo do Poder Judiciário para trabalhar o conflito em sua integralidade, é possível afirmar-se que em algumas oportunidades a sentença não pacifica a relação social, persistindo o conflito.

As técnicas de solução extrajudicial de conflitos surgem, portanto, como alternativa não só à excessiva quantidade de processos e ao elevado custo da estrutura judiciária, mas, principalmente, como mecanismos que se têm mostrado eficientes na resolução de conflitos. Nesta perspectiva foi que se desenvolveu o conceito de "Tribunal Multiportas", criado por Goldberg et al. (2017, p. 236) e que, originariamente, denominava-se "centro abrangente de justiça" (GOLDBERG et al., 2017, 
p. 235).

Consoante se depreende de referido autor, em entrevista concedida a Mariana Hernadez Crespo na obra de Almeida, Almeida e Crespo (2012, p. 32), o nome "Tribunal Multiportas" surgiu após uma matéria de capa de uma das revistas da ABA (American Bar Association - Ordem dos Advogados dos Estados Unidos), que retratava uma grande quantidade de portas para representar sua teoria.

A teoria de Goldberg et al. (2017, p. 248) baseia-se na ideia de estudar as várias formas de resolução de conflitos, dentre eles a mediação, arbitragem, negociação e med-arb (combinação entre mediação e arbitragem), a fim de classificá-las e ser capaz de indicar quais seriam adequadas para determinados tipos de conflitos.

Miranda Netto e Leal $(2015$, p. 9) exprimem opinião que sintetiza bem a ideia do conceito de Tribunal Multiportas, ao afirmarem:

Os diversos métodos de resolução de conflitos existentes não estão postos para concorrerem entre si, mas, na realidade, para fazer frente à necessidade de se multiplicarem as vias de acesso à justiça, de forma a conferir a cada tipo de conflito a solução mais adequada, haja vista a convicção de que o Poder Judiciário não pode dar conta de qualquer problema.

Com base no pensamento desses autores, infere-se que "com a ideia de Tribunal Multiportas, o Poder Judiciário deve passar necessariamente por uma reformulação que redefina suas atribuições, adotando a ideia de "um novo aspecto da substitutividade, que revela qual é a maneira mais adequada de condução daquele conflito" (MIRANDA NETTO; LEAL, 2015, p. 10). Parte-se, portanto, para a necessidade de se diferenciar o acesso à justiça do acesso ao Poder Judiciário, estando este, na realidade, contido naquele.

O Poder Judiciário, ainda segundo Miranda Netto e Leal (2015, p. 14), vivencia uma crise em virtude do "excesso de demanda que o próprio Judiciário criou para si em seu caminho de multiplicação de portas, em que, ao invés de se utilizar de sua posição de destaque para promover o acesso a outras instâncias de tratamento de conflitos, optou-se pela centralização das atividades".

Com base nisso afirmam Holmes e Sunstein (2019, p. 31) que "a tutela de direitos, independentemente de sua geração, exige do Estado o dispêndio de vultosas somas, a fim de fazer frente às despesas necessárias à atuação do Poder Judiciário". Todavia, dada a escassez de recursos caracterizadora da Economia, inexistem fundos disponíveis para fazer frente a todas as despesas necessárias a uma efetiva atuação do Poder Judiciário, motivo pelo qual os meios alternativos de solução de conflitos surgem como oportunidades de efetivarem-se direitos a baixos ou, pelo menos, menores custos do que aqueles demandados por um processo judicial.

Compreendendo este novo viés de acesso à justiça, o Conselho Nacional de Justiça do Poder Judiciário brasileiro acolheu o conceito de "Tribunal Multiportas" através de sua Resolução $n^{\circ} 125 / 2010$, que, reformada em 2013, instituiu “a Política Judiciária Nacional de tratamento dos conflitos de interesses", prevista nos seguintes termos (CNJ, 2010): 
Art. $1^{\circ}$ Fica instituída a Política Judiciária Nacional de tratamento dos conflitos de interesses, tendente a assegurar a todos o direito à solução dos conflitos por meios adequados à sua natureza e peculiaridade.

Parágrafo único. Aos órgãos judiciários incumbe, nos termos do art. 334 do Novo Código de Processo Civil combinado com o art. 27 da Lei de Mediação, antes da solução adjudicada mediante sentença, oferecer outros mecanismos de soluções de controvérsias, em especial os chamados meios consensuais, como a mediação e a conciliação, bem assim prestar atendimento e orientação ao cidadão.

Impende ressaltar que a adoção da doutrina do "Tribunal Multiportas" não importa em um enfraquecimento ou desmerecimento do Poder Judiciário, mas em verdade subsiste como uma das portas adequadas à solução de conflitos. É natural que nem todos os conflitos possam ser solucionados por intermédio de um dos demais mecanismos de soluções de controvérsias, devendo a via judicial, portanto, subsistir como alternativa.

\section{OS JUIZADOS ESPECIAIS CÍVEIS E AS FUNÇÕES DO DIREITO, À LUZ DA DOUTRINA MULTIPORTAS}

Dentro do panorama da solução judicial dos conflitos, concebida esta enquanto uma das portas acessíveis, identificou-se a existência de determinadas espécies de conflitos cuja busca de solução judicial restava prejudicada em uma perspectiva do sistema comum de justiça.

Nesse sentido o acesso à justiça é considerado um “direito social básico nas modernas sociedades" (CAPPELLETTI; GARTH, 2015, p. 18); porém, deve-se buscar a sua efetividade. Em um plano abstrato, a efetividade perfeita poderia ser entendida como uma "igualdade de armas", em que ambos os litigantes dispusessem dos mesmos mecanismos, e a conclusão final do processo, nesse caso, dependeria apenas do mérito jurídico. Existem, porém, alguns obstáculos a serem superados, dos quais podem ser elencados as custas judiciais, as possibilidades das partes e os problemas especiais dos interesses difusos.

Ainda segundo os referidos autores, dentro da problemática das custas judiciais, de um modo geral, podem-se extrair três óbices a serem superados pelos litigantes: "o valor em si das custas, o problema relacionado às causas de pequeno valor e o tempo de duração dos processos, fator de desestímulo para os litigantes, que os acaba incentivando a fazerem acordo por valores inferiores ao que teriam direito" (CAPPELLETTI; GARTH, 2015, p. 20).

Os Juizados Especiais, em seu perfil institucional, englobam esses três elementos dificultadores, ressaindo como órgão judicial que os tencionava superar. Fato é que, na estrutura pátria do Poder Judiciário, surgiram inicialmente os Juizados de Pequenas Causas, regulados pela Lei $n^{\circ} 7.244 / 84$, e que possuíam sua competência estabelecida no artigo $3^{\circ}$ de referida norma, a seguir transcrito (BRASIL, 1984):

Art. $3^{\circ}$ - Consideram-se causas de reduzido valor econômico as que versem 
sobre direitos patrimoniais e decorram de pedido que, à data do ajuizamento, não exceda a 20 (vinte) vezes o salário mínimo vigente no País e tenha por objeto: I - a condenação em dinheiro;

II - a condenação à entrega de coisa certa móvel ou ao cumprimento de obrigação de fazer, a cargo de fabricante ou fornecedor de bens e serviços para consumo; III - a desconstituição e a declaração de nulidade de contrato relativo a coisas móveis e semoventes.

$\S 1^{\circ}$ - Esta Lei não se aplica às causas de natureza alimentar, falimentar, fiscal e de interesse da Fazenda Pública, nem às relativas a acidentes do trabalho, a resíduos e ao estado e capacidade das pessoas, ainda que de cunho patrimonial.

$\S 2^{\circ}$ - A opção pelo procedimento previsto nesta Lei importará em renúncia ao crédito excedente ao limite estabelecido neste artigo, excetuada a hipótese de conciliação.

Os Juizados de Pequenas Causas, porém, foram em pouco tempo substituídos pelos Juizados Especiais Cíveis e Criminais, os quais, no âmbito cível, tiveram sua competência ampliada, nos termos do art. $3^{\circ}$ da Lei ${ }^{\circ}$ 9.099/95 (BRASIL, 1995):

Art. $3^{\circ} \mathrm{O}$ Juizado Especial Cível tem competência para conciliação, processo e julgamento das causas cíveis de menor complexidade, assim consideradas:

I - as causas cujo valor não exceda a quarenta vezes o salário mínimo;

II - as enumeradas no art. 275, inciso II, do Código de Processo Civil;

III - a ação de despejo para uso próprio;

IV - as ações possessórias sobre bens imóveis de valor não excedente ao fixado no inciso I deste artigo.

$\S 1^{\circ}$ Compete ao Juizado Especial promover a execução:

I - dos seus julgados;

II - dos títulos executivos extrajudiciais, no valor de até quarenta vezes o salário mínimo, observado o disposto no $\S 1^{\circ}$ do art. $8^{\circ}$ desta Lei.

$\S 2^{\circ}$ Ficam excluídas da competência do Juizado Especial as causas de natureza alimentar, falimentar, fiscal e de interesse da Fazenda Pública, e também as relativas a acidentes de trabalho, a resíduos e ao estado e capacidade das pessoas, ainda que de cunho patrimonial.

$\S 3^{\circ}$ A opção pelo procedimento previsto nesta Lei importará em renúncia ao crédito excedente ao limite estabelecido neste artigo, excetuada a hipótese de conciliação.

O surgimento de tais unidades jurisdicionais deu-se com o objetivo de conferir mais uma opção de mecanismo de solução de litígios. Vários aspectos da Lei n 9.099/95 ressaltam a adoção por tal norma do conceito de Tribunal Multiportas, exemplificativamente em seus artigos $1^{\circ}, 2^{\circ} \mathrm{e}$ $9^{\circ}$, que seguem (BRASIL, 1995):

Art. $1^{\circ}$ Os Juizados Especiais Cíveis e Criminais, órgãos da Justiça Ordinária, serão criados pela União, no Distrito Federal e nos Territórios, e pelos Estados, para conciliação, processo, julgamento e execução, nas causas de sua competência. Art. $2^{\circ} \mathrm{O}$ processo orientar-se-á pelos critérios da oralidade, simplicidade, informalidade, economia processual e celeridade, buscando, sempre que possível, 
a conciliação ou a transação.

Art. $9^{\circ}$ Nas causas de valor até vinte salários mínimos, as partes comparecerão pessoalmente, podendo ser assistidas por advogado; nas de valor superior, a assistência é obrigatória.

Os Juizados Especiais Cíveis e Criminais possuem um viés de atuação voltado para a conciliação, muito embora não deixem de lado a solução jurisdicional dos litígios, caso essa se afigure como necessária. Ademais, possuem regras que se coadunam com o tipo de demanda a que se destinam, pautando-se por critérios que simplificam e desburocratizam o trâmite processual, inclusive dispensando em determinadas hipóteses a presença de advogado, a fim de tornar menos oneroso do ponto de vista econômico o litígio para os envolvidos.

Infere-se de Cappelletti e Garth (2015, p. 107) que uma das características dos Juizados Especiais Cíveis, tendente a garantir um maior acesso à justiça, é a possibilidade de o juiz atuar mais ativamente na condução do processo, especialmente na formação da prova, a fim de equilibrar as partes, principalmente aquelas desassistidas de advogados. A Lei 9.099/95 resguarda essa atuação mais ativa quando, em seu artigo $5^{\circ}$, dispõe que "o Juiz dirigirá o processo com liberdade para determinar as provas a serem produzidas, para apreciá-las e para dar especial valor às regras de experiência comum ou técnica" (BRASIL, 1995).

A partir da legislação que rege os Juizados Especiais Cíveis, podem-se elencar algumas previsões normativas que trouxeram maior acessibilidade à justiça, como, por exemplo:

a) a possibilidade de prática de atos processuais à noite (art. 12);

b) redução de formalidades, como a possibilidade de registro do pedido independentemente de distribuição e autuação (art. 16) e a possibilidade de instauração imediata da sessão de conciliação, dispensados o registro prévio do pedido e a citação, caso compareçam inicialmente as partes (art. 17);

c) a possibilidade de conversão do procedimento judicial em arbitragem (art. 24).

O Direito, como regulador social que é, há que desempenhar a função de fomentador do bem comum na sociedade, entendendo-se o bem comum como a compatibilização entre os interesses individuais conflitantes, e entre os individuais e coletivos, que também carreguem consigo o traço da divergência.

Tais conflitos - absolutamente naturais na vida em sociedade - podem ser de cooperação e de concorrência, sendo a natureza da atividade o aspecto determinante da inserção em um ou em outro tipo. Os primeiros - conflitos de cooperação - são oriundos de uma relação social que em sua gênese possui uma convergência de interesses como, verbi gratia, comprador e vendedor. Os segundos - conflitos de concorrência - a seu turno, decorrem de relações que já em seu início trazem como apanágio uma divergência, não necessariamente de cunho beligerante, como, por exemplo, dois comerciantes do mesmo ramo de atividade. 
Dessa forma, têm-se atividades de cooperação e concorrência, nas quais podem ocorrer conflitos de interesses. Nesse sentido, tem-se que

O conflito se faz presente a partir do impasse quando os interesses envolvidos não logram solução pelo diálogo, e as partes recorrem à luta, moral ou física, ou buscam a mediação da justiça. Podemos defini-lo como oposição de interesses, entre pessoas ou grupos, não conciliados pelas normas sociais (CAVALIERI FILHO, 2019, p. 38).

Nesse diapasão, surge a necessidade de pôr fim ao conflito; em um estado ideal, é preferível que este sequer se instaure, sendo reprimido antes mesmo de principiar. Eis aqui esboçadas, respectivamente, as funções compositiva e preventiva do Direito.

A função precípua do Direito é a de se antecipar à pretensão resistida - a lide - tentando evitar sua ocorrência (função preventiva), pois que o litígio originado pelo conflito possui como corolário o desequilíbrio das relações sociais e, por óbvio, o comprometimento do atingimento e manutenção da pacificação social.

No entanto, em razão da própria contingência caracterizadora do fenômeno jurídico - a deontologia - ressai que o Direito deixa aos indivíduos a liberdade de seguirem ou não os seus preceitos. Todavia, caso haja a transgressão, surge a possibilidade de uma reprimenda jurídica. Origina-se propriamente o conflito, que reclama solução, dada a ojeriza da sociedade à continuidade dessa situação de desarmonia. Eis aqui a secundária, mas igualmente importante função do Direito, a saber, a compositiva, que deve ser utilizada de maneira fragmentária.

Atente-se para o fato que a função compositiva não consiste em fazer o conflito não mais existir no meio social, pois sempre haverá quem transgrida as normas de conduta: deflagrado o conflito, cumpre sopesar os interesses antagônicos e determinar qual deve prevalecer e qual deve ser reprimido, ainda que apenas para as circunstâncias daquele caso concreto específico.

Imperioso, nesse instante, abordar os principais critérios de composição de conflitos, a saber, o da composição voluntária (ou por autonomia da vontade das partes), o autoritário e o da composição jurídica.

O critério da composição voluntária é verdadeira inclinação mundial, inclusive fomentado pelo próprio Poder Judiciário, vez que reduz a carga de trabalho deste, sendo, como regra, mais célere e eficaz. Como exemplos legislativos no Brasil observe-se os artigos 21 a 26 da Lei ${ }^{\circ}$ 9.099/95 (BRASIL, 1995):

Art. 21. Aberta a sessão, o Juiz togado ou leigo esclarecerá as partes presentes sobre as vantagens da conciliação, mostrando-lhes os riscos e as consequências do litígio, especialmente quanto ao disposto no $\S 3^{\circ}$ do art. $3^{\circ}$ desta Lei.

Art. 22. A conciliação será conduzida pelo Juiz togado ou leigo ou por conciliador sob sua orientação.

Parágrafo único. Obtida a conciliação, esta será reduzida a escrito e homologada pelo Juiz togado, mediante sentença com eficácia de título executivo.

Art. 23. Não comparecendo o demandado, o Juiz togado proferirá sentença.

Art. 24. Não obtida a conciliação, as partes poderão optar, de comum acordo, pelo 
juízo arbitral, na forma prevista nesta Lei.

$\S 1^{\circ} \mathrm{O}$ juízo arbitral considerar-se-á instaurado, independentemente de termo de compromisso, com a escolha do árbitro pelas partes. Se este não estiver presente, o Juiz convocá-lo-á e designará, de imediato, a data para a audiência de instrução. $\S 2^{\circ} \mathrm{O}$ árbitro será escolhido dentre os juízes leigos.

Art. 25. O árbitro conduzirá o processo com os mesmos critérios do Juiz, na forma dos arts. $5^{\circ}$ e $6^{\circ}$ desta Lei, podendo decidir por equidade.

Art. 26. Ao término da instrução, ou nos cinco dias subsequentes, o árbitro apresentará o laudo ao Juiz togado para homologação por sentença irrecorrível.

Observe-se que a própria legislação induz o jurisdicionado a aderir a este mecanismo alternativo - ou adequado - de resolução de conflitos, ao asseverar que "o Juiz togado ou leigo esclarecerá as partes presentes sobre as vantagens da conciliação, mostrando-lhes os riscos e as consequências do litígio", o que, segundo nossa percepção, afigura-se como a opção mais acertada.

O critério autoritário, a seu turno, é apanágio de sociedades primitivas, embora possa-se ainda hodiernamente verificarem-se resquícios, mormente no meio familiar. Neste critério incumbe à autoridade do grupo social a prerrogativa de restaurar a ordem transgredida. Em regra, o chefe do grupo emprega sua própria perspectiva de justiça, logo, de foro íntimo, para decidir sobre o conflito de interesses.

O critério de composição jurídica alberga o princípio da substitutividade, sendo aquele pautado por parâmetros elaborados pública e previamente. Seus elementos caracterizadores são, pois, a anterioridade, vez que o critério antecede o próprio conflito, dado que a lei, genérica tende a adquirir aplicabilidade a partir do instante em que o fato social se amolde às prescrições desta; a publicidade, em razão que a todos deve ser possibilitado o conhecimento dos parâmetros antes de sua aplicação e, finalmente, a universalidade ou generalidade, pois não podem ser engendrados para dada situação particular, mas sim para todos os homogêneos casos que se adequarem ao disposto em lei.

Nessa toada, o caráter multiportas dos JEC's se mostra como medida que, embora compositiva de conflitos, confere maior autonomia entre os litigantes para transigirem, vez que não será composição jurídica no sentido mais estrito do vocábulo, tendendo, dessa forma, a ser mais efetivo, em função de se afigurar como o menos beligerante.

\section{O PERFIL EXIGIDO DA ADVOCACIA ANTE A REALIDADE DOS MECANISMOS DE DESJUDICIALIZAÇÃO}

Caminhando ao encontro dessa realidade de desjudicialização, os pretórios brasileiros vêm consagrando a expressão "advogado do futuro", para se referir ao profissional que pugna por evitar a demanda, ao invés de instigar sua proposição. Possui, pois, predileção por medidas extrajudiciais de resolução de conflitos, sendo muito mais um mediador de conflitos que propriamente um incitador destes, e desta forma pavimentando a rota para que o Direito efetive sua principal razão: a consecução e manutenção da paz social. 
Tais mecanismos adequados de resolução de conflitos, segundo o alcance da expressão neste ensaio adotado, é caminho que, se não irreversível, é, ao menos, de bastante difícil volta, e isso traz como desdobramento natural impactos na atividade advocatícia, que necessitará adaptarse a tal realidade. A própria natureza multiportas dos JEC's os compele a romper com o perfil conservador - e belicoso - que norteou e norteia a mentalidade de expressiva parcela dos advogados "produzidos" em terrae brasilis, impulsionada pela formação tradicional das academias pátrias, igualmente carentes de passar por essa filtragem, pois, caso contrário, tenderão - o ensino jurídico brasileiro e o advogado em si - a pavimentar o caminho para o ostracismo intelectual e profissional.

Até para ilustrar este perfil que se exige da advocacia nesse contexto, com o propósito de verificar a aplicabilidade, em termos práticos, dos JEC's como Tribunal Multiportas no Brasil, trazemos a análise de um case hipotético, que poderia ser solucionado por meio de mecanismos alternativos ao Judiciário.

Inicialmente, há que se atentar para a competência dos JEC's, estabelecida no art. $3^{\circ}$, inciso IV, da Lei 9.099/95 e já transcrito acima, que traz sua atribuição para julgar "as ações possessórias sobre bens imóveis de valor não excedente ao fixado no inciso I deste artigo" (BRASIL, 1995).

Especificamente sobre o inciso IV (ações possessórias), versará o caso hipotético proposto tendo por objetivo findar conflitos de interesses oriundos de direitos de vizinhança, pois que se tratam de direitos transacionáveis, além do fato de poucas relações sociais a esta fazerem frente quando o assunto é beligerância. Essa a razão pela qual se escolheu esta exemplificação. Não nos referimos aqui apenas aos casos de vicinalidade absoluta, mas a todas as situações que, em razão da proximidade, possam fazer surgirem exigibilidades garantidas.

Delimitando, analisar-se-á a figura do interdito proibitório como postulante a resolver situação de uso anormal da propriedade, sua possível impotência para tal, e como a figura dos JEC's como Tribunal Multiportas poderia equacionar a problemática. Imagine-se a seguinte situação hipotética:

João da Silva, possuidor de apartamento vizinho ao de Antônio Oliveira, aprecia ouvir músicas que, segundo este, além de serem de muito mau gosto, incomodam pelo elevado volume, pois, segundo lhe parece, excedem o que seria razoável, assim como o horário, segundo seu juizo, mostra-se demasiado impertinente. Antônio tentou resolver a situação amistosamente por algumas vezes, mas sem êxito, em razão da recalcitrância de João. Dessa forma, Antônio 'perdeu a paciência' e ameaçou destruir o aparelho de som e o próprio imóvel pertencentes a João. Assim, João tenciona ingressar junto ao JEC (Lei 9.099/95, art. 3", "IV" e "I") com a ação de interdito proibitório, para solucionar o problema." 
Primeiramente, a resolução pela via tradicional, judicial, a partir do interdito proibitório. Esta ação é espécie do gênero interditos possessórios, ao lado da reintegração de posse e da manutenção de posse. Tem aquele caráter preventivo de defesa da posse, incidindo quando há ameaça a esta (não se confundindo com o exercício regular de direito), ou seja, não houve ainda ato material agressor, mas promessa de agressão idônea a gerar justo receio no possuidor ameaçado que a turbação ou esbulho venham de fato a ocorrer.

Como dispositivos aplicáveis ao caso veja-se os artigos 1.210 e 1.277 do Código Civil, que seguem abaixo (BRASIL, 2002, grifo nosso):

Art. 1.210. O possuidor tem direito a ser mantido na posse em caso de turbação, restituído no de esbulho, e segurado de violência iminente, se tiver justo receio de ser molestado.

Art. 1.277. O proprietário ou o possuidor de um prédio tem o direito de fazer cessar as interferências prejudiciais à segurança, ao sossego e à saúde dos que o habitam, provocadas pela utilização de propriedade vizinha.

Esse o panorama doutrinário e legal do instituto que, como regra, acaba por ser o mais utilizado em situações deste jaez.

Agora os JEC's como Tribunal Multiportas para resolver a mesma situação. Chegando este caso no JEC, este encaminha para o CEJUSC (Centro Judiciário de Solução de Conflitos e Cidadania), que é uma unidade do Poder Judiciário especializada em atendimento ao público para a solução consensual de conflitos e orientação nas matérias relativas à cidadania. $\mathrm{O}$ atendimento é feito por mediadores e conciliadores capacitados e registrados no NUPEMEC (Núcleo Permanente de Métodos Consensuais de Solução de Conflitos), vinculado ao Tribunal de Justiça do Estado.

Tal encaminhamento ao CEJUSC intenta fazer com que os litigantes cheguem a um denominador comum, por meio de concessões recíprocas, rumo à efetivação da pacificação social. Os conflitos envolvendo direitos de vizinhança são bastante propícios a serem solucionados extrajudicialmente, vez que os vizinhos não necessariamente teriam no Poder Judiciário uma solução satisfatória, pois, mesmo este possuindo a legitimidade para julgar (a substitutividade), pode eventualmente não pacificar a desavença. Ao revés, muitas vezes apenas acirra a animosidade entre os envolvidos, haja vista que nem sempre o final de um processo vai importar no final do conflito, pois ninguém melhor que as próprias partes envolvidas na situação concreta para saberem o que será melhor para ambas.

\section{CONCLUSÃO}

À luz do exposto, percebeu-se que a substutividade conferida ao Poder Judiciário, vale dizer, conceber esta função estatal como protagonista na resolução de conflitos de interesses, foi, durante séculos, o principal (se não o único) meio de solução de conflitos, empregando-se, pois, o comando judicial como a solução para as lides que ao mesmo chegavam. 
É fato, todavia, que a pacificação social nem sempre é alcançada através da solução judicialmente proposta, posto que a ausência de efetiva participação dos litigantes na sua construção faz com que, muitas vezes, estes não se sintam pessoalmente obrigados a cumpri-la, ensejando o emprego de violência para o seu cumprimento forçado.

Noutros termos, verificou-se que o provimento jurisdicional até pode pôr fim ao processo; no entanto, mostrou-se impotente para promover a pacificação social, não raro fomentando o clima de beligerância entre as partes. Não bastasse isso, a própria demora na resposta do Poder Judiciário fortalece essa situação, além de inviabilizar preceito de envergadura constitucional, qual seja, o da duração razoável do processo.

A doutrina do Tribunal Multiportas chama a atenção para tal circunstância, instando os principais atores do litígio (partes, advogados e juízes) a buscarem a solução pela via mais adequada à sua natureza, pois, reitere-se, que ninguém possui mais idoneidade para definir qual a decisão mais acertada a tomar para a pacificação que as próprias partes, por meio de concessões recíprocas. E isso em menor tempo e com menos desgastes emocionais e financeiros.

Essa nova perspectiva de resolução do litígio foi adotada pelo Poder Judiciário pátrio, através de Resolução do Conselho Nacional de Justiça - CNJ -, e o Juizado Especial Cível, antes mesmo da referida normatização infralegal, que já atendia aos requisitos necessários para ser considerado, sem sombra de dúvidas, uma destas portas, dotando as partes e o juízo de mecanismos tendentes à construção conjunta da solução do conflito e, por isso mesmo, mais efetivas do ponto de vista material - ou "resolver realmente" o problema -, dentro de um lapso temporal razoável.

Nesse contexto, a mudança de postura da advocacia, privilegiando a desjudicialização, assume posição central para a efetivação da pacificação social e da duração razoável do processo.

\section{REFERENCIAS}

ALMEIDA, Rafael Alves de; ALMEIDA, Tania; CRESPO, Mariana Hernandez. Tribunal Multiportas: investindo no capital social para maximizar o sistema de solução de conflitos no Brasil. Rio de Janeiro: FGV, 2012.

BRASIL. Lei $\mathbf{n}^{\mathbf{0}}$ 10.406, de 10 de janeiro de 2002. Institui o Código Civil. Brasília: Presidência da República, 2002. Disponível em: http://www.planalto.gov.br/ccivil_03/leis/2002/110406.htm. Acesso em: 25 maio 2019.

BRASIL. Lei $\mathbf{n}^{\mathbf{0}} \mathbf{7 . 2 4 4}$, de 7 de novembro de 1984. Dispõe sobre a criação e o funcionamento do Juizado Especial de Pequenas Causas. Brasília: Presidência da República, 1984. Disponível em: http://www.planalto.gov.br/ccivil_03/leis/1980-1988/17244.htm. Acesso em: 15 maio 2019.

BRASIL. Lei n 9.099, de 26 de setembro de 1995. Dispõe sobre os Juizados Especiais Cíveis e Criminais e dá outras providências. Brasília: Presidência da República, 1995. Disponível em: http://www.planalto.gov.br/ccivil_03/leis/19099.htm. Acesso em: 17 abr. 2019. 
CAPPELLETTI, Mauro; GARTH, Bryant. Acesso à justiça. Porto Alegre: Sérgio Antônio Fabris Editor, 2015.

CAVALIERI FILHO, Sérgio. Programa de sociologia jurídica. 15. ed. São Paulo: Atlas, 2019.

CNJ - CONSELHO NACIONAL DE JUSTIÇA. Justiça em números 2018: ano-base 2017. Brasília: CNJ, 2018. Disponível em: https://www.cnj.jus.br/wp-content/uploads/conteudo/arquiv o/2018/08/44b7368ec6f888b383f6c3de40c32167.pdf. Acesso em: 5 dez. 2018.

CNJ - CONSELHO NACIONAL DE JUSTIÇA. Resolução n ${ }^{\circ} \mathbf{1 2 5}$, de 29 de novembro de 2010. Dispõe sobre a Política Judiciária Nacional de tratamento adequado dos conflitos de interesses no âmbito do Poder Judiciário e dá outras providências. Brasília: CNJ, 2010. Disponível em: https://www.cnj.jus.br/wp-content/uploads/2011/02/Resolucao_n_125-GP.pdf. Acesso em: 20 nov. 2018.

ENTELMAN, Remo. Teoría de conflictos: hacia un nuevo paradigma. Barcelona: Editorial Gedisa, 2009.

FERREIRA, Lier Pires; GUANABARA, Ricardo; JORGE, Vladimyr Lombardo (org.). Curso de sociologia jurídica. Rio de Janeiro: Elsevier, 2011.

GOLDBERG, Stephen B.; SANDER, Frank E. A.; ROGERS, Nancy H.; COLE, Sarah Rudolph. Dispute resolution: negotiation, mediation and other processes. 7. ed. Aspen: Wolters Kluwer, 2017.

HOBBES, Thomas. The elements of law: natural and politic. Cambridge: Cambridge University Press, 2018.

HOLMES, Stephen; SUNSTEIN, Cass R. O custo dos direitos: por que a liberdade depende dos impostos. São Paulo: Martins Fontes, 2019.

LOCKE, John. Segundo tratado sobre o governo civil e outros. Petrópolis: Vozes, 2019.

MENDES, Conrado Hübner. Controle de constitucionalidade e democracia. Rio de Janeiro: Elsevier, 2008.

MIRANDA NETTO, Fernando Gama de; LEAL, Stela Tannure. Tribunal multiportas e crises de identidade: o Judiciário como alternativa a si mesmo? In: ORSINI, Adriana Goulart de Sena; MAILLART, Adriana Silva; SANTOS, Nivaldo dos (coord.). Formas consensuais de solução de conflitos. Florianópolis: CONPEDI, 2015. p. 5-33.

\section{VATTEL, Emmerich de. Derecho de gentes, o Principios de la ley natural aplicados} A LA CONDUCTA E INTERESES de LAS NACIONES E dE LOS PRÍNCIPES. NEW YORK: MOML PRINT EDITIONS, 2016.

WATANABE, Kazuo. Acesso à ordem jurídica justa. Belo Horizonte: Del Rey, 2018. 
Como citar: SILVA, Diego Sabóia e; PONTES, David Gomes. A doutrina do tribunal multiportas e sua aplicabilidade nos juizados especiais cíveis do Brasil. Scientia Iuris, Londrina, v. 24, n. 1, p. 39-54, mar. 2020. DOI 10.5433/21788189.2020v24n1p39. ISSN 2178-8189.

Recebido em: 09/09/2019

Aprovado em: 20/02/2020 